\title{
Keanekaragaman semut dan pola keberadaannya pada daerah urban di Palu, Sulawesi Tengah
}

\section{Ant diversity and its occurrence in Palu urban area, Central Sulawesi}

\author{
Hasriyanty $^{{ }^{*}}$, Akhmad Rizali ${ }^{2}$, Damayanti Buchori ${ }^{3}$ \\ 'Program Studi Agroteknologi, Fakultas Pertanian, Universitas Tadulako \\ Kampus Bumi Tadulako Tondo. Jalan Soekarno Hatta Km 9, Palu 94118 \\ ${ }^{2}$ Jurusan Hama dan Penyakit Tumbuhan, Fakultas Pertanian, Universitas Brawijaya \\ Jalan Veteran, Malang 65145 \\ ${ }^{3}$ Departemen Proteksi Tanaman, Fakultas Pertanian, Institut Pertanian Bogor \\ Jalan Kamper, Kampus IPB Darmaga, Bogor 16680
}

(diterima Juli 2013, disetujui Agustus 2013)

\begin{abstract}
ABSTRAK
Konversi habitat dari hutan menjadi area pertanian atau kawasan permukiman, disamping menyebabkan penurunan keanekaragaman hayati juga menimbulkan permasalahan baru, seperti kehadiran hama. Di kawasan permukiman, salah satu hama urban yang cukup mengganggu adalah semut. Penelitian ini bertujuan untuk mempelajari pola keberadaan semut urban pada permukiman di Palu, Sulawesi Tengah. Penelitian dilaksanakan pada berbagai tipe habitat meliputi perumahan, kebun, taman, semak, pertanian hingga pinggiran hutan. Semut dikoleksi dengan menggunakan perangkap umpan berupa ikan tuna dan gula. Sebanyak 38 spesies semut ditemukan pada keseluruhan gradien habitat di daerah urban di Palu. Keanekaragaman semut memiliki hubungan erat dengan kondisi habitat. Kekayaan dan komposisi spesies semut cenderung meningkat dengan penurunan tingkat gangguan manusia (dari habitat perumahan ke hutan). Semut yang paling dominan dan ditemukan pada keseluruhan habitat adalah Anoplolepis gracilipes, Solenopsis geminata dan Paratrechina longicornis. Ketiga spesies semut ini merupakan spesies semut tramp yang biasa berasosiasi dengan manusia dan bersifat invasif yang berpengaruh negatif tidak hanya bagi keanekaragaman hayati tapi juga bagi manusia. Urbanisasi dan keberadaan manusia memfasilitasi keberadaan semut invasif di daerah urban di Palu.
\end{abstract}

Kata kunci: hama urban, tipe habitat, perangkap umpan, semut tramp

\begin{abstract}
Land-use change, mainly from natural forest to agricultural or settlement area, beside have negative impact on biodiversity also cause a new problem such as the presence of pests. In urban area, the most intrusive and common pest is ant. The objective of this research was to study the occurrence pattern of ants in urban habitat. The research was conducted in several urban habitat in of Palu, Central Sulawesi include of settlement, garden, city park, shrub, agricultural area and forest margin. Ants were observed with bait trap using tuna and sugar. In total, we found 38 ant species from all gradients of urban habitat in Palu. Ant diversity were significantly correlated with habitat condition. Species richness and composition of ants tend to increase with decreasing degree of human disturbance (from settlement to forest margin). The most dominant ant that always found in all urban habitat are Anoplolepis gracilipes, Solenopsis geminata and Paratrechina longicornis. Those species are wellknown as tramp species that co-exist with human and have negative impact
\end{abstract}

\footnotetext{
*Penulis korespondensi: Hasriyanty. Program Studi Agroteknologi, Fakultas Pertanian, Universitas Tadulako,

Kampus Bumi Tadulako Tondo, Jalan Soekarno Hatta Km 9, Palu, Sulawesi Tengah

Tel: 0451-422611, Faks: 0451-429738, Email: hasrianty_amran@yahoo.com
} 
to local ant species. Urbanization and anthropological disturbance facilitate the occurrence of tramp ant species in Palu urban habitat.

Key words: urban pest, habitat type, bait trap, tramp ant species

\section{PENDAHULUAN}

Hubungan manusia dengan serangga urban telah dimulai sejak keberadaan manusia (Robinson 1996). Manusia secara tidak sengaja memfasilitasi serangga dengan menyediaan sumber makanan, tempat bersarang yang sesuai serta membantu penyebaran dari satu tempat ke tempat lainnya (Gullan \& Cranston 2010). Di daerah urban, kebiasaan serangga dalam mencari makan dan bersarang menjadi permasalahan sendiri. Sebagai contoh, aktivitas rayap dalam mencari makan pada perumahan menimbulkan kerugian yang sangat besar (Cowie et al. 1989). Bahkan beberapa serangga, seperti nyamuk mengakibatkan kematian bagi manusia karena sebagai vektor penyakit (Lounibos 2002). Aktivitas mencari makan dan kebiasaan bersarang semut pada peralatan rumah tangga juga mengakibatkan kerugian bagi manusia (Rizali et al. 2008).

Sebagai kelompok serangga yang paling melimpah dan hampir ditemukan pada semua habitat terrestrial (Hölldobler \& Wilson 1990; Wilson 1990) menjadikan semut berpotensi menguntungkan maupun merugikan bagi manusia. Beberapa kelompok semut mampu beradaptasi dengan baik pada lingkungan manusia. Kelompok semut ini yang biasa disebut semut tramp berasosiasi sangat dekat dengan manusia dan ditemukan melimpah pada habitat yang terganggu, area pertanian hingga perumahan, bahkan umumnya wilayah aslinya berasal dari luar daerah distribusinya (McGlynn 1999). Keberadaan spesies tramp berdampak negatif bagi keanekaragaman hayati dan bahkan bagi manusia (Holway et al. 2002; O’Dowd et al. 2003).

Perubahan habitat sangat memengaruhi keberadaan semut. Respon semut yang sangat sensitif terhadap perubahan habitat menjadikan semut dapat digunakan sebagai bioindikator dari gangguan habitat (Andersen 1997; Peck et al. 1998; Andersen 2000), termasuk juga pengaruh aplikasi pestisida (Matlock \& de la Cruz 2002). Beberapa spesies semut mampu memanfaatkan terjadinya peningkatan suhu melalui peningkatan aktivitas dan jumlah koloni, yang menyebabkan perubahan struktur komunitas melalui mekanisme kompetisi (Gibb \& Hochuli 2003). Keberadaan tempat bersarang yang sesuai juga memengaruhi keberadaan semut. Sebagai contoh, perkakas rumah tangga dan makanan yang tersimpan dirumah menjadikan habitat yang sesuai untuk tempat bersarang dan mencari makan bagi semut tramp (Rizali et al. 2008).

Hubungan antara spesies tramp dan habitat pada daerah urban telah banyak dipelajari, sebagai contoh penelitian mengenai semut urban di daerah Bogor (Rizali et al. 2008). Walaupun demikian, masih belum banyak penelitian mengenai pengaruh urbanisasi terhadap semut (McIntyre et al. 2001; Smith et al. 2006). Bahkan penelitian ekologi pada daerah urban umumnya difokuskan pada kelompok serangga lain misalnya kupu-kupu (Koh \& Sodhi 2004; Collier et al. 2006) pada habitat taman dan hutan kota.

Penelitian ini bertujuan mempelajari keanekaragaman semut dan pola keberadaannya pada daerah urban di Palu, Sulawesi Tengah. Palu merupakan wilayah perkotaan yang terletak di daerah teluk dan dikelilingi oleh pegunungan sehingga memiliki gradien penggunaan habitat dan ketinggian yang bervariasi. Selain itu, wilayah Palu termasuk kawasan disekitar garis Walacea menjadikan wilayah ini memiliki sejarah keanekaragaman hayati yang tinggi pada masa lalu. Berdasarkan hal tersebut, maka hal ini menjadi menarik untuk mempelajari status keberadaan dari spesies lokal dan sekaligus pendatang pada wilayah ini.

\section{BAHAN DAN METODE}

\section{Lokasi penelitian}

Penelitian dilaksanakan pada daerah urban di Palu, Sulawesi Tengah (Gambar 1). Daerah urban di Palu dikelompokkan menjadi 8 tipe habitat, yaitu pantai, perumahan, taman kota, semak, sawah, ladang, perkebunan dan pinggiran hutan (Tabel 1). Ketinggian lokasi dari setiap habitat 
dikelompokkan menjadi tiga kelompok ketinggian, yaitu $<100 \mathrm{~m}, 100-200 \mathrm{~m}$, dan $>200 \mathrm{~m}$ di atas permukaan laut (dpl). Di setiap habitat ditentukan 6 plot untuk pengambilan contoh semut. Khusus pada habitat kebun, sawah, dan semak masingmasing sebanyak 12 plot, sedangkan habitat rumah jumlah plot untuk pengambilan contoh sebanyak
24 plot untuk mengetahui pola keberadaan semut secara khusus pada habitat-habitat tersebut.

\section{Pengamatan dan pengambilan contoh semut}

Pengamatan dan pengambilan contoh semut pada setiap plot dilakukan dengan metode umpan menggunakan ikan tuna kaleng dan madu untuk

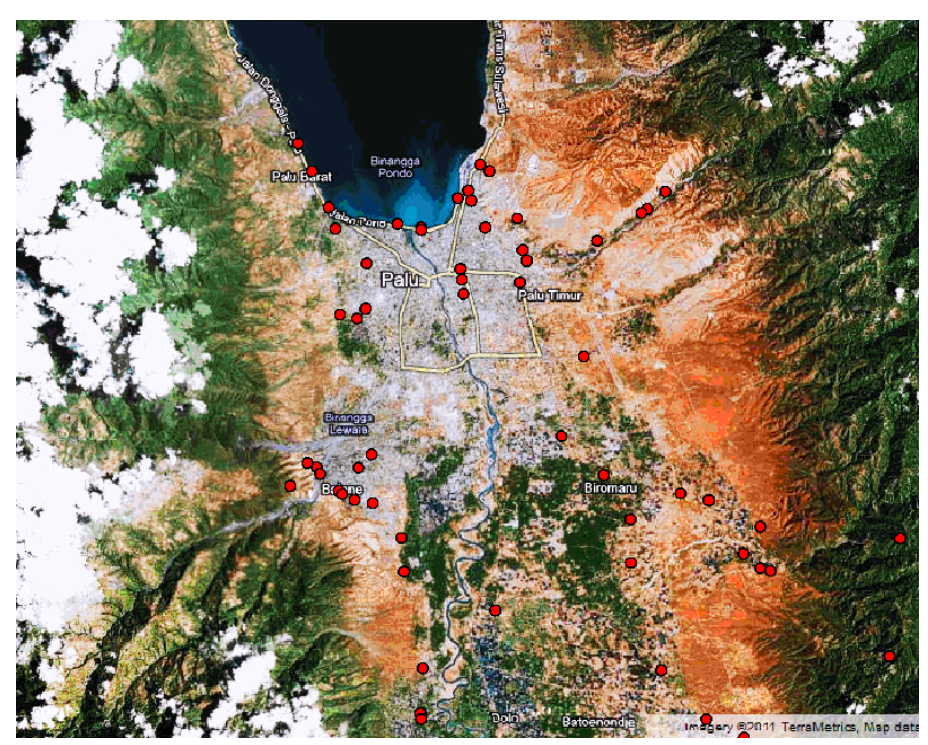

Gambar 1. Persebaran plot pengambilan contoh (titik berwarna merah) pada daerah urban di Palu Sulawesi Tengah yang mencakup berbagai kondisi habitat hingga perbedaan ketinggian.

Tabel 1. Lokasi penelitian semut urban di lembah Palu, Sulawesi Tengah

\begin{tabular}{|c|c|c|c|}
\hline Ketinggian (m dpl) & Habitat & Jumlah plot & Deskripsi habitat \\
\hline \multirow[t]{7}{*}{$<100$} & Rumah & 12 & $\begin{array}{l}\text { Rumah penduduk meliputi dalam rumah dan } \\
\text { pekarangan }\end{array}$ \\
\hline & Pantai & 6 & Habitat di pantai \\
\hline & Taman & 6 & $\begin{array}{l}\text { Taman atau daerah hijau yang terdapat di dalam } \\
\text { kota }\end{array}$ \\
\hline & Sawah & 6 & Persawahan yang ditanam padi \\
\hline & Semak & 6 & $\begin{array}{l}\text { Lahan kering yang tidak ditanami tanaman budi } \\
\text { daya }\end{array}$ \\
\hline & Ladang & 6 & Lahan kering yang ditanami tanaman budi daya \\
\hline & Kebun & 6 & Perkebunan tanaman kakao \\
\hline \multirow[t]{4}{*}{$100-200$} & Rumah & 6 & $\begin{array}{l}\text { Rumah penduduk meliputi dalam rumah dan } \\
\text { pekarangan rumah }\end{array}$ \\
\hline & Sawah & 6 & Persawahan yang ditanami tanaman padi \\
\hline & Semak & 6 & $\begin{array}{l}\text { Lahan kering yang tidak ditanami tanaman budi } \\
\text { daya }\end{array}$ \\
\hline & Kebun & 6 & Perkebunan tanaman kakao \\
\hline \multirow[t]{3}{*}{$>200$} & Rumah & 6 & $\begin{array}{l}\text { Rumah penduduk meliputi dalam rumah dan } \\
\text { pekarangan rumah }\end{array}$ \\
\hline & Hutan & 6 & Habitat pada tepian hutan \\
\hline & Total & 84 & \\
\hline
\end{tabular}


memperoleh berbagai jenis semut dan sekaligus mengetahui peranan semut pada habitat tersebut (Wielgoss et al. 2010). Pengambilan contoh dilakukan selama 1 jam dengan mengamati semut yang mengunjungi umpan setiap 15 menit. Jumlah semut dihitung dan beberapa individu dikoleksi menggunakan alkohol $70 \%$ untuk kemudian dibawa ke laboratorium untuk identifikasi. Di setiap plot, pengambilan contoh dilakukan pada dua waktu berbeda, yaitu pagi hari jam 09:00 10:00 dan sore hari jam 15:00-16:00. Pengambilan contoh di lapangan dilaksanakan pada bulan JuliDesember 2010.

\section{Identifikasi spesimen semut}

Seluruh spesimen diidentifikasi sampai tingkat genus dengan mengacu pada Bolton (1994). Setelah itu, spesimen diidentifikasi hingga tingkat morfospesies. Tingkatan morfospesies, yaitu pendekatan identifikasi semut hingga tingkat spesies berdasarkan perbedaan karakter dari tiap genus yang ditemukan (Lattke 2000).

\section{Analisis data}

Kurva akumulasi spesies (Colwell \& Coddington 1994) digunakan untuk mengetahui perbedaan keanekaragaman semut antar habitat dan keefektifan metode pangambilan contoh yang digunakan. Perbedaan komposisi spesies semut antar habitat dianalisis dengan menggunakan analisis Ordihull berdasarkan indeks ketidakmiripan Braycurtis. Keseluruhan analisis tersebut dilakukan dengan menggunakan perangkat lunak R Statistic (R Development Core Team 2011).

\section{HASIL}

\section{Keanekaragaman semut pada daerah urban di Palu}

Keanekaragaman semut yang ditemukan pada berbagai habitat daerah urban di Palu berjumlah 38 spesies dari 6 subfamili (Tabel 2, Tabel 3). Beberapa spesies hanya ditemukan pada habitat tertentu, seperti Aenictus sp.01, Cerapachys sp.01, Nylanderia sp.05, dan Ponera sp.01 yang hanya ditemukan di habitat perumahan. Spesies yang tergolong dalam kelompok tramp dan invasif ditemukan pada keseluruhan habitat daerah urban (Tabel 3).
Berdasarkan jumlah plot yang digunakan, secara umum metode yang digunakan berhasil mengkoleksi sebagian besar semut pada setiap habitat. Habitat pantai, taman, dan sawah hampir keseluruhan spesies semut terkoleksi menurut nilai estimasi Chao, yaitu secara berurutan 100\%, 99\%, dan $96 \%$. Estimasi terendah (75\%) pada habitat rumah dan pinggiran hutan yang menandakan bahwa pada habitat-habitat tersebut memiliki keanekaragaman yang seharusnya lebih tinggi dibandingkan dengan keanekaragaman semut yang diperoleh. Hal tersebut ditunjukkan pula dari kurva akumulai spesies (Gambar 2) dimana habitat hutan (6 plot) dan rumah (24 plot) masih terlihat menunjukkan peningkatan.

\section{Pola keberadaan semut di daerah urban}

Berdasarkan jumlah spesies semut yang diperoleh pada setiap habitat, menunjukkan bahwa kondisi habitat memengaruhi keberadaan dan komposisi spesies semut pada daerah urban. Jumlah spesies semut cenderung meningkat berdasarkan penurunan tingkat gangguan, yaitu secara berurutan mulai dari rumah, pantai, taman, semak, sawah, kebun, ladang, dan hutan (Gambar 3). Rumah dengan tingkat gangguan tinggi memiliki keanekaragaman semut paling rendah dibandingkan dengan habitat ladang atau hutan.

Hasil analisis perbedaan komposisi spesies dengan menggunakan Ordihull juga menunjukkan pola yang sama (Gambar 4). Perbedaan komposisi atau ketidakmiripan (dissimilarity) spesies semut cenderung meningkat dengan menurunnya tingkat gangguan dari suatu habitat. Hal berbeda

Tabel 2. Jumlah dan perkiraan jumlah spesies semut (berdasarkan estimasi Chao) dari berbagai habitat urban di Palu

\begin{tabular}{lrcc}
\hline Habitat & Plot & $\begin{array}{c}\text { Jumlah } \\
\text { spesies }\end{array}$ & Estimasi (Chao) \\
\hline Rumah & 24 & 18 & $24(75 \%)$ \\
Pantai & 6 & 8 & $8(100 \%)$ \\
Taman & 6 & 10 & $10(99 \%)$ \\
Semak & 12 & 18 & $20(89 \%)$ \\
Sawah & 12 & 22 & $23(96 \%)$ \\
Kebun & 12 & 20 & $26(77 \%)$ \\
Ladang & 6 & 20 & $26(77 \%)$ \\
Hutan & 6 & 20 & $26(75 \%)$ \\
Total & 84 & 38 & $38(100 \%)$ \\
\hline & & &
\end{tabular}


Tabel 3. Keanekaragaman semut pada berbagai habitat urban di Palu. $(*)$ : spesies semut tramp dan (**): spesies semut tramp dan invasif (McGlynn 1999). Rmh: perumahan; Pnt: Pantai; Tmn: taman kota; Smk: semak; Swh: sawah; Kbn: perkebunan kakao; Ldg: ladang; Htn: pinggiran hutan

\begin{tabular}{|c|c|c|c|c|c|c|c|c|c|}
\hline No & Spesies & $\mathrm{Rmh}$ & Pnt & Tmn & Smk & Swh & Kbn & Ldg & Htn \\
\hline \multicolumn{10}{|c|}{ Aenictinae } \\
\hline & Aenictus sp.01 & + & & & & & & & \\
\hline \multicolumn{10}{|c|}{ Cerapachyinae } \\
\hline & Cerapachys sp.01 & + & & & & & & & \\
\hline \multicolumn{10}{|c|}{ Dolichoderinae } \\
\hline 3. & Dolichoderus thoracicus & + & & & + & + & + & & + \\
\hline 4. & Iridomyrmex sp.01 & + & + & + & + & + & & & + \\
\hline 5. & Iridomyrmex sp.02 & & & & & + & & & \\
\hline 6. & Tapinoma melanocephalum * & + & + & + & + & + & + & + & + \\
\hline 7. & Tapinoma sp.01 & & & & + & & & + & + \\
\hline 8. & Technomyrmex sp.01 & + & & & & & & + & + \\
\hline \multicolumn{10}{|c|}{ Formicinae } \\
\hline 9. & Anoplolepis gracilipes $* *$ & + & + & + & + & + & + & + & + \\
\hline 10. & Camponotus sp.01 & + & & + & & & & & \\
\hline 11. & Camponotus sp.02 & + & & & & + & & & \\
\hline 12. & Camponotus sp.03 & & & & & + & + & & + \\
\hline 13. & Cladomyrma sp.01 & & & & & + & & & \\
\hline 14. & Nylanderia sp.01 & + & + & & + & + & + & & + \\
\hline & Nylanderia sp.02 & + & & & + & + & + & + & + \\
\hline 16. & Nylanderia sp.03 & & & & + & + & + & + & \\
\hline 17. & Nylanderia sp.04 & & & & & + & & & + \\
\hline & Nylanderia sp.05 & + & & & & & & & \\
\hline 19. & Oechophylla smaragdina & & & + & + & + & + & + & \\
\hline 20. & Paratrechina longicornis $* *$ & + & + & + & + & + & + & + & + \\
\hline & Polyrhachis sp.01 & & & & & + & & & \\
\hline & Pseudolasius sp.01 & & & & & & & + & \\
\hline \multicolumn{10}{|c|}{ Myrmicinae } \\
\hline 23. & Lophomyrmex sp.01 & & & & & & + & & \\
\hline 24. & Monomorium floricola * & + & + & + & + & + & + & + & + \\
\hline 25. & Monomorium sp.01 & + & & & + & + & + & + & + \\
\hline 26. & Monomorium sp.02 & & & & + & + & + & + & \\
\hline 27. & Monomorium sp.03 & + & & & + & + & + & + & + \\
\hline & Monomorium sp.04 & & & & & & & + & \\
\hline 29. & Oligomyrmex sp.01 & & & & & & + & & \\
\hline 30. & Paratopula sp.01 & & & & & & & & + \\
\hline 31. & Pheidole sp.01 & + & & & & + & + & + & \\
\hline 32. & Solenopsis geminata $*$ & + & + & + & + & + & + & + & + \\
\hline 33. & Tetramorium bicarinatum * & + & + & + & + & & + & + & + \\
\hline 34. & Tetramorium sp.01 & & & & + & & & & + \\
\hline 35. & Tetramorium sp.02 & & & & & & & + & \\
\hline \multicolumn{10}{|c|}{ Ponerinae } \\
\hline 36. & Diacamma rugosum & & & + & + & + & + & + & + \\
\hline 37. & Odontomachus sp.01 & & & & & & + & + & + \\
\hline 38. & Ponera sp.01 & + & & & & & & & \\
\hline
\end{tabular}




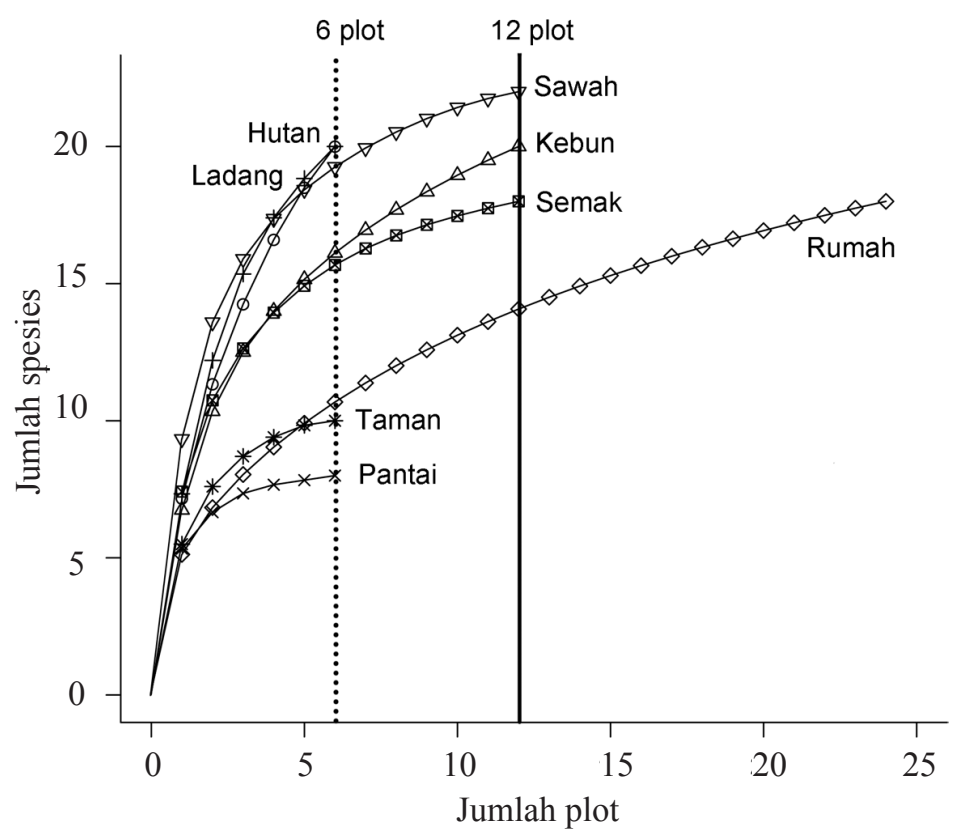

Gambar 2. Kurva akumulasi spesies semut yang ditemukan pada berbagai habitat urban di Palu dengan menggunakan metode rarefaction.

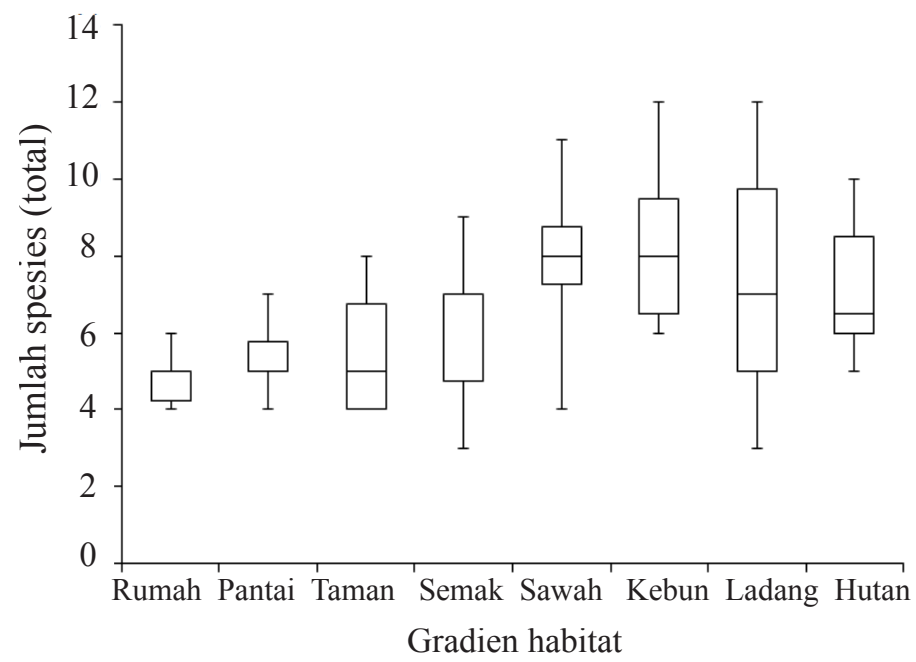

Gambar 3. Keanekaragaman semut yang ditemukan pada setiap jenis habitat. Data dengan menggunakan jumlah plot yang sama $(n=6)$.

ditunjukkan pada kelompok spesies semut tramp, yang menunjukkan tidak terdapat pola perbedaan pada gradien habitat urban yang ada di Palu (Gambar 5). Habitat yang berbeda tidak memengaruhi keberadaan spesies semut tramp yang selalu ditemukan pada keseluruhan jenis habitat.

\section{PEMBAHASAN}

Keanekaragaman semut pada daerah urban di Palu, Sulawesi Tengah memiliki kesamaan dengan keanekaragaman semut di Bogor, Jawa
Barat (Rizali et al. 2008) yang didominasi oleh spesies semut invasif. Jumlah spesies semut yang ditemukan melalui penelitian ini tidak sebanyak jumlah spesies semut yang ditemukan di Bogor. Hal ini karena metode pengambilan contoh yang dilakukan di Bogor menggunakan metode pengambilan semut intensif sehingga dapat diperoleh berbagai jenis semut pada berbagai mikro habitat. Sebagai contoh pada habitat sawah, jumlah spesies yang terkoleksi didalam penelitian ini sebanyak 22 spesies jauh dibawah hasil penelitian Rizali et al. (2008) yang menemukan 36 spesies semut. Perbedaan ini selain dipengaruhi oleh metode pengambilan contoh yang berbeda 


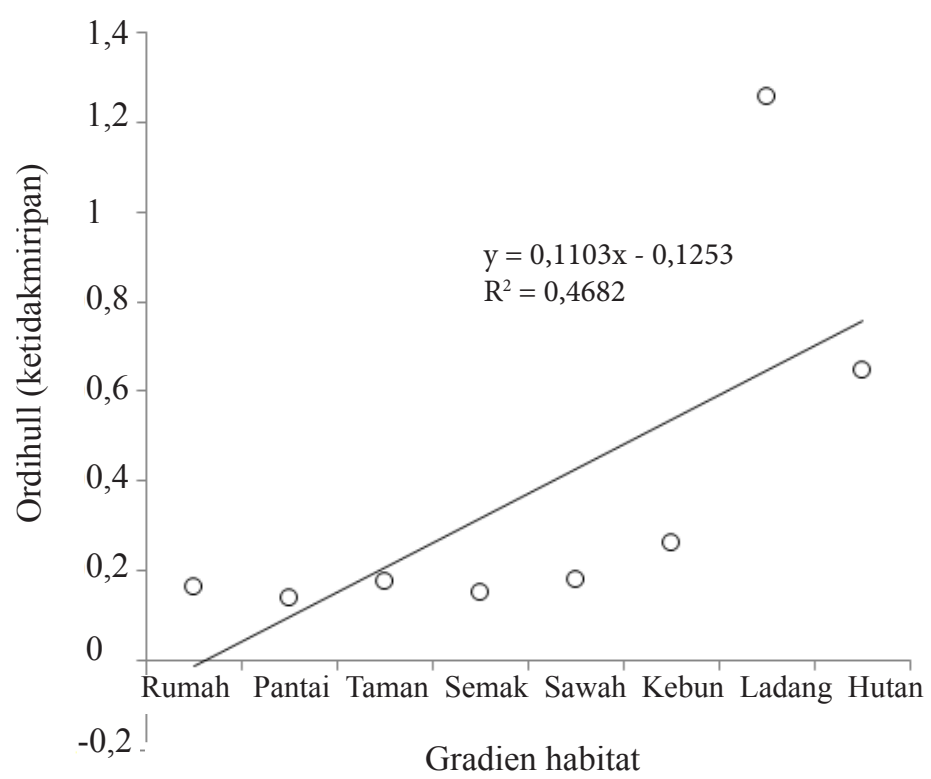

Gambar 4. Ordihull ketidakmiripan komposisi spesies dari keseluruhan habitat di Palu. Data berdasarkan jumlah plot yang sama $(n=6)$.

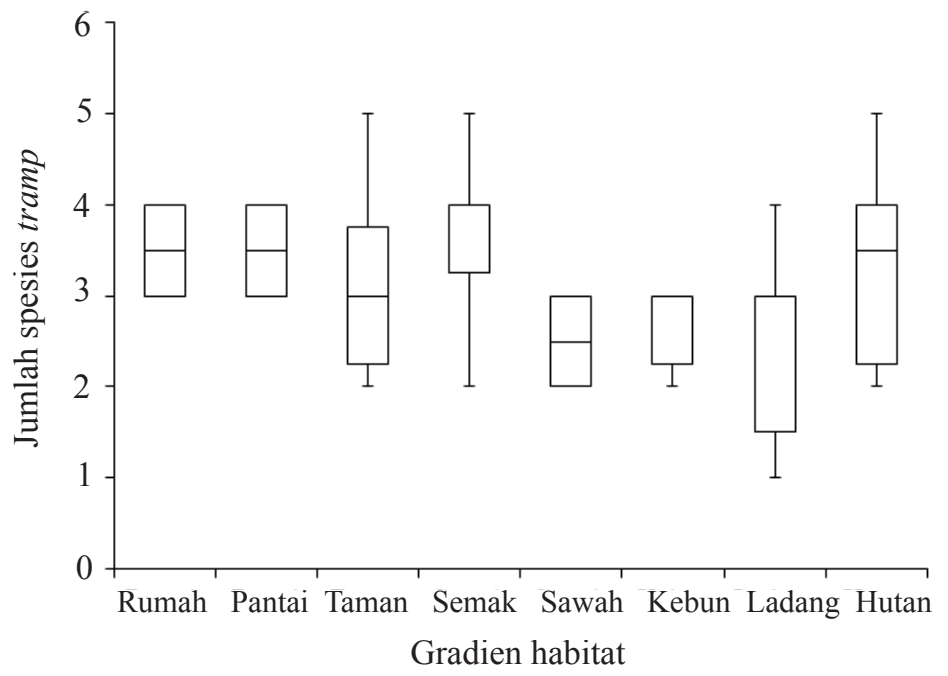

Gambar 5. Keanekaragaman spesies semut tramp pada setiap habitat. Dengan menggunakan jumlah plot yang sama $(n=6)$.

juga diduga disebabkan oleh letak geografis dan kondisi habitat persawahan yang berbeda antara Bogor dan Palu.

Semakin tinggi tingkat gangguan habitat, keanekaragaman maupun keberadaan spesies semut yang ditemukan cenderung semakin meningkat. Habitat dengan intensitas gangguan tinggi, seperti perumahan, pantai, dan taman, hanya dapat memfasilitasi keberadaan spesies semut tramp yang mampu beradaptasi terhadap gangguan manusia (Gibb \& Hochuli 2003). Keberadaan semut tramp yang bersifat invasif, seperti Anoplolepis gracilipes (Smith), Paratrechina longicornis (Latreille), dan Solenopsis geminata (Fabricius) disamping mampu beradaptasi pada habitat terganggu juga menyebabkan hilangnya spesies semut yang lain karena kalah berkompetisi (Holway et al. 2002).

Intensitas gangguan habitat juga memengaruhi perbedaan komposisi spesies semut pada daerah urban. Di habitat yang sedikit mengalami gangguan, seperti tepian hutan atau ladang, kemiripan komposisi spesies semutnya semakin rendah dibandingkan dengan kemiripan komposisi spesies semut pada habitat yang terganggu. Komposisi spesies semut pada habitat terganggu cenderung lebih mirip disebabkan oleh dominasi oleh spesies semut tertentu yang lebih mampu beradaptasi. Selain itu ketersediaan makanan, tempat bersarang, dan iklim mikro juga memengaruhi keberadaan spesies semut tertentu (Andersen 2000). 
Habitat yang terganggu dan keberadaan spesies invasif disinyalir memberikan efek negatif ganda terhadap keanekaragaman semut yang ada di daerah urban di Palu. Habitat terganggu cenderung memfasilitasi spesies semut tertentu khususnya dalam mendukung ketersediaan pakan semut tramp (Kaspari \& Majer 2000), sedangkan spesies invasif menyebabkan hilangnya spesies semut yang lain (Holway et al. 2002). Hal tersebut perlu menjadi perhatian khusus dalam pengelolaan kawasan konservasi yang terletak di daerah urban. Palu yang terletak di Pulau Sulawesi merupakan pulau yang memiliki keanekaragaman hayati tinggi (Whitten et al. 2002), dan kemungkinan memiliki keanekaragaman semut yang juga tinggi yang potensinya belum dimanfaatkan.

\section{KESIMPULAN}

Pola keberadaan semut pada daerah urban di Palu, Sulawesi Tengah dipengaruhi oleh jenis habitat dan intensitas gangguan manusia pada habitat tersebut. Semakin rendah intensitas gangguan manusia maka keanekaragaman semut cenderung semakin tinggi. Perbedaan komposisi spesies semut juga dipengaruhi oleh kondisi habitat di daerah urban, komposisi spesies semut cenderung lebih mirip pada habitat yang memiliki tingkat gangguan yang tinggi. Pengaruh keberadaan spesies invasif juga memberikan kontribusi terhadap keberadaan spesies semut yang lain.

\section{UCAPAN TERIMA KASIH}

Penelitian ini dibiayai oleh Direktorat Pendidikan Tinggi (Dikti) melalui Penelitian Strategis Unggulan, Institut Pertanian Bogor tahun 2010. Terima kasih kepada Siti Zualikah, Jomes, dan Fadlian yang telah membantu dalam pengambilan contoh di lapangan serta kepada Herlianti Hasan yang membantu proses sortir dan identifikasi di laboratorium. Selain itu kepada Adha Sari, kami mengucapkan terima kasih atas bantuan administratif sehingga penelitian ini dapat terlaksana dengan lancar.

\section{DAFTAR PUSTAKA}

Andersen AN. 1997. Using ants as bioindicators: multiscale issues in ant community ecology. Available at: http://www.consecol.org/vol1/iss1/ art8/ [accessed 8 Juli 2013].

Andersen AN. 2000. Global ecology of rainforest ants: functional groups in relation to environmental stress and disturbance. In: Agosti D, Majer JD, Alonso LE, Schultz TR (Eds.), Ants: Standard Methods for Measuring and Monitoring Biodiversity. pp. 25-34. Washington: Smithsonian Institution Press.

Bolton B. 1994. Identification Guide to the Ant Genera of the World. Cambridge: Harvard University Press.

Collier N, MacKay DA, Benkendorff K, Austin AD, Carthew SM. 2006. Butterfly communities in South Australian urban reserves: Estimating abundance and diversity using the Pollard walk. Australian Ecology 31:282-290. doi: http:// dx.doi.org/10.1111/j.1442-9993.2006.01577.x.

Colwell RK, Coddington JA. 1994. Estimating terrestrial biodiversity through extrapolation. Philosophical Transactions of the Royal Society B: Biological Sciences 345:101-118. doi: http:// dx.doi.org/10.1098/rstb.1994.0091.

Cowie RH, Logan JWM, Wood TG. 1989. Termite (Isoptera) damage and control in tropical forestry with special reference to Africa and IndoMalaysia: a review. Bulletin of Entomological Research 79:173-184. doi: http://dx.doi.org/10. 1017/S0007485300018150.

Gibb H, Hochuli DF. 2003. Colonisation by a dominant ant facilitated by anthropogenic disturbance: effects on ant assemblage composition, biomass and resource use. Oikos. 103:469-478. doi: http://dx.doi.org/10.1034/ j.1600-0706.2003.12652.x.

Gullan PJ, Cranston PS. 2010. The Insects: An Outline of Entomology. Oxford: Wiley-Blackwell.

Hölldobler B, Wilson EO. 1990. The Ants. Cambridge: Harvard University Press. doi: http: //dx.doi.org/10.1007/978-3-662-10306-7.

Holway DA, Lach L, Suarez AV, Tsutsui ND, Case TJ. 2002. The causes and consequences of ant invasions. Annual Review of Ecology and Systematics 33:181-233. doi: http://dx.doi.org/ 10.1146/annurev.ecolsys.33.010802.150444.

Kaspari M, Majer JD. 2000. Using ants to monitor enviromental change. In: Agosti D, Majer JD, Alonso LE, Schultz TR (Eds.), Ants: Standard 
Methods for Measuring and Monitoring Biodiversity. pp: 89-98. Washington: Smithsonian Institution Press.

Koh LP, Sodhi NS. 2004. Importance of reserves, fragments, and parks for butterfly conservation in a tropical urban landscape. Ecological Appli cations. 14:1695-1708. doi: http://dx.doi.org/10. 1890/03-5269.

Lattke JE. 2000. Specimen processing: building and curating an ant collection. In: Agosti D, Majer JD, Alonso LE, Schultz TR (Eds.), Ants: Standard Methods for Measuring and Monitoring Biodiversity. pp. 155-171. Washington: Smithsonian Institution Press.

Lounibos LP. 2002. Invasions by insect vectors of human disease. Annual Review of Entomology 47:233. doi: http://dx.doi.org/10.1146/annurev. ento.47.091201.145206.

Matlock RB Jr, de la Cruz R. 2002. An inventory of Parasitic Hymenoptera in banana plantations under two pesticide regimes. Agriculture, Ecosystems \& Environment 93:147-164. doi: http://dx.doi.org/10.1016/S0167-8809(02)0000 2-6.

McGlynn TP. 1999. The worldwide transfer of ants: geographical distribution and ecological invasions. Journal of Biogeography 26:535548. doi: http://dx.doi.org/10.1046/j.1365-2699. 1999.00310.x.

McIntyre NE, Rango J, Fagan WF, Faeth SH. 2001. Ground arthropod community structure in a heterogeneous urban environment. Landscape Urban Planning 52:257-274. doi: http://dx.doi. org/10.1016/S0169-2046(00)00122-5.

O’Dowd DJ, Green PT, Lake PS. 2003. Invasional 'meltdown' on an oceanic island. Ecology Letters 6:812-817. doi: http://dx.doi.org/10.1046/j.14610248.2003.00512.x.
Peck SL, Mcquaid B, Campbell CL. 1998. Using ant species (Hymenoptera: Formicidae) as a biological indicator of agroecosystem condition. Environmental Entomology 27:1102-1110. doi: http://dx.doi.org/10.1093/ee/27.5.1102.

R Development Core Team. 2011. $R$ : A language and environment for statistical computing. Vienna: $\mathrm{R}$ Foundation for Statistical Computing.

Rizali A, Bos MM, Buchori D, Yamane S, Schulze CH. 2008. Ants in tropical urban habitats: the myrmecofauna in a densely populated area of Bogor, West Java, Indonesia. HAYATI Journal of Biosciences 15:77-84.

Robinson WH. 1996. Urban Entomology: Insect and mite pests in the human environment. London: Chapman \& Hall. doi: http://dx.doi. org/10.1007/978-1-4613-0437-1.

Smith J, Chapman A, Eggleton P. 2006. Baseline biodiversity surveys of the soil macrofauna of London's green spaces. Urban Ecosystems 9:337-349. doi: http://dx.doi.org/10.1007/ s1125-2-006-0001-8.

Whitten AJ, Mustafa M, Henderson GS. 2002. The ecology of Sulawesi. Hong Kong: Periplus.

Wielgoss A, Tscharntke T, Buchori D, Fiala B, Clough Y. 2010. Temperature and a dominant dolichoderine ant species affect ant diversity in Indonesian cacao plantations. Agriculture, Ecosystems \& Environment 135:253-259. doi: http://dx.doi.org/10.1016/j.agee.2009.10.003.

Wilson EO. 1990. Success and Dominance in Ecosystems: The Case of Social Insects. Olderdorf/Luhe: Ecology Institut. 